\title{
POTENSI DAUN JAMBU BIJI SEBAGAI AGENT ANTIDIABETIK TRADISIONAL
}

\author{
Agustina Fadilla Gunata \\ Fakultas Kedokteran, Universitas Lampung, Jl. Prof. DR. Ir. Sumatri Brojonegoro No.1, Gedong Meneng, \\ Kec. Rajabasa, Kota Bandar Lampung, Lampung, Indonesia 35145 \\ agustinafadilla1708@gmail.com (+6282178868484)
}

\begin{abstract}
ABSTRAK
Peningkatan kasus diabetes mellitus yang kian meningkat didukung oleh berbagai faktor resiko terutama obesitas akibat pola hidup tidak sehat. Peningkatan diabetes mellitus tipe 2 didominasi di wilayah perkotaan akan tetapi secara global peningkatan di semua daerah. Tujuan literature review ini adalah mengetahui potensi daun jambu biji sebagai agen antidiabetik tradisional. Artikel ini menggunakan metode studi artikel review, yaitu menggunakan artikel penelitian yang didapar melalui proses literature searching terkait potensi daun jambu biji sebagai agen antidiabetik tradisional dari tahun 2010 sampai tahun 2020. Berbagai penelitian eksperimental yang dilakukan menunjukkan bahwa ekstrak daun jambu biji bermanfaat sebagai antidiabetik tradisional. Daun jambu biji memiliki beberapa senyawa bioaktif yaitu asam fenolik berperan ganda sebagai antioksidan dan menghambat enzim Alfaglukosidase dalam proses pencernaan karbohidrat sehingga menurunkan kadar glukosa postprandial. Senyawa aktif lainnya seperti Quercetin, Asam betulinic dan Lupeol berperan terhadap menurunkan kolesterol, trigiserida serta bersifat hipoadiponectin. Kombinasi bahan aktif lainnya bekerja secara sinergis.
\end{abstract}

Kata kunci: daun jambu biji; enzim alfaglukosidase; hipoglikemik; hipoadiponectin

\section{THE POTENTIAL OF GUAVA LEAVES AS TRADITIONAL ANTIDIABETIC AGENTS}

\begin{abstract}
The increasing number of diabetes mellitus cases is supported by various risk factors, especially obesity due to unhealthy lifestyles. The increase in type 2 diabetes mellitus is dominated in urban areas but globally the increase in all areas. The puspose of this literature review is to determine the potential of guava leaves as a traditional antidiabetik agent. The method of this article is using article review by searching the articles related to the potential of guava leaves as a tradisional antidiabetik from year 2010 to 2020. Various experimental studies conducted showed that guava leaves has potential activity as antidiabetik. Guava leaves have several bioactive compounds, namely phenolic acids that play a dual role as antioxidants and inhibit the Alfaglucosidase enzyme in the digestion of carbohydrates, thereby reducing postprandial glucose levels. Other active compounds such as Quercetin, Betulinic Acid, and Lupeol play a role in lowering cholesterol, triglycerides, and are hypoadiponectin. The combination of other active ingredients works synergistically.
\end{abstract}

Keywords: guava leaves; alfaglucosidase enzyme; hypoglycemic; hypoadiponectin

\section{PENDAHULUAN}

Peningkatan gaya hidup mempengaruhi pola kesehatan seseorang. Perubahan jenis makanan dan lingkungan menjadi salah satu resiko tinggi berdampak pada kondisi metabolik. Salah satu penyakit metabolik yang kian meningkat yaitu diabetes mellitus. Diabetes mellitus merupakan penyakit metabolik kronis yang diakibatkan menurunnya produksi 
insulin atau menurunnya respon reseptor dari insulin tersebut. Berdasarkan data International Diabetes Federation (IDF) terdapat 463 juta orang pada usia 20-79 tahun di dunia pada tahun 2019 atau setara dengan angka prevalensi sebesar 9,3\% dari total penduduk pada usia yang sama. Berdasarkan jenis kelamin, IDF memperkirakan prevalensi diabetes di tahun 2019 yaitu 9\% pada perempuan dan $9,65 \%$ pada laki-laki. Prevalensi diabetes pada usia 65-79 tahun sebesar $19,9 \%$ atau 111,2 juta orang. Prediksikan hingga mencapai 578 juta di tahun 2030 dan 700 juta di tahun 2045 (Anderson et al, 2019)

Negara di wilayah Arab-Afrika Utara, dan Pasifik Barat menempati peringkat pertama mempunyai prevalensi diabetes pada penduduk umur 20-79 tahun tertinggi di antara 7 regional di dunia, yaitu sebesar $12,2 \%$ dan 11,4\%. Wilayah Asia Tenggara dimana Indonesia berada, menempati peringkat ke-3 dengan prevalensi sebesar 11,5\%. Indonesia berada di peringkat ke-7 di antara 10 negara dengan jumlah penderita terbanyak, yaitu sebesar 10,7 juta. Sehingga menjadikan Indonesia satu-satunya negara di Asia Tenggara pada daftar tersebut dan berkontribusi utama terhadap prevalensi kasus diabetes di Asia Tenggara (Anderson et al, 2019).

Hasil Penelitian Riset Kesehatan Dasar (Riskesdas) pada tahun 2018 melakukan pengumpulan data penderita diabetes melitus pada penduduk berumur $>15$ tahun. Berdasarkan diagnosis dokter didapatkan peningkatan sebesar $2 \%$. Dibandingkan pada hasil Riskesdas 2013 sebesar 1.5\%. Prevalensi diabetes melitus menurut hasil pemeriksaan gula darah meningkat dari 6,9\% pada 2013 menjadi $8.5 \%$ pada tahun 2018. Angka ini menunjukkan bahwa baru sekitar $25 \%$ penderita diabetes yang mengetahui bahwa dirinya menderita diabetes (Riskesdas, 2018).

Penegakan diagnosis diabetes mellitus begitu penting dan utama dimana mengacu pada kriteria diabetes melitus pada Risksesdas 2018 mengacu pada konsensus Perkumpulan Endokrinologi Indonesia (PERKENI) yang mengadopsi kriteria American Diabetes Association (ADA). Menurut kriteria tersebut, diabetes mellitus ditegakkan bila kadar glukosa darah puasa $=126$ $\mathrm{mg} / \mathrm{dl}$, atau glukosa darah 2 jam pasca pembebanan $=200 \mathrm{mgl} / \mathrm{dl}$, atau glukosa darah sewaktu > $200 \mathrm{mg} / \mathrm{dl}$ dengan gejala sering lapar, sering haus, sering buang air kecil dan dalam jumlah banyak, dan berat badan turun (Riskesdas, 2018; Soelistijo et al, 2019)

Faktor resiko berperan penting terhadap terjadinya diabetes mellitus. Faktor resiko baiknya dilakukan upaya pengendalian yang akan mempunyai dampak sebagai pencegahan dan menurunkan mortalitas serta morbiditas. Faktor resiko diabetes terdiri dari faktor yang dapat dimodifikasi dan faktor yang tidak dapat dimodifikasi, Faktor risiko yang tidak dapat dimodifikasi adalah ras, etnik, urnur, jenis kelamin, riwayat keluarga dengan diabetes mellitus, riwayat melahirkan bayi> 4.000 gram, rivayat lahir dengan berat badan lahir rendah (BBLR atau < 2.500 gram).

Sedangkan faktor resiko yang dapat dimodifikasi salah satunya adalah obesitas, dimana dikatakan obesitas jika nilai Indeks Massa Tubuh (IMT) $\geq 27$ (Anderson et al, 2019). Di Indonesia angka obesitas makin meningkat $21,08 \%$ pada tahun 2019 dan menjadi tantangan sendiri bagi Indonesia menghadapi double burden. Proporsi 
penderita diabetes melitus menurut tingkat pendidikan menunjukkan bahwa responden tingkat pendidikan tamat akademi/universitas memiliki proporsi tertinggi pada Riskesdas tahun 2013 dan Riskesdas tahun 2018, yaitu sebesar $2,5 \%$ dan $2,8 \%$. Penderita diabetes melitus pada responden di wilayah perkotaan lebih tinggi dibandingkan yang tinggal di perdesaan, yaitu 2\% berbanding 1\% pada Riskesdas 2013 dan $1,89 \%$ berbanding $1,01 \%$ pada Riskesdas 2019, Hal ini dapat diasumsikan adanya akses terhadap deteksi kasus di pelayanan kesehatan yang lebih baik pada wilayah perkotaan dibandingkan perdesaan (Riskesdas, 2013).

Pencegahan merupakan kunci utama untuk menuntaskan peningkatan kasus diabetes akan tetapi pengobatan maksimal dengan menyediakan berbagai terapi menjadi hal kedua terpenting. Terapi alternative yang dapat dijadikan adalah dengan menggunakan bahan alam yang mudah dijangkau dan tersedia di masyarakat. Salah satu bahan alam yang memiliki potensi sebagai agent antidiabetes adalah daun jambu biji yang dikenal memiliki kadar polifenol sebagai antioksidant. Diharapkan adanya pembaruan dari bahan alam untuk menjadi agent terapi diabetes baru yang lebih baik dan optimal dengan harga terjangkau di masyarakat.

\section{METODE}

Penulisan jurnal ini menggunakan metode studi article review. Kepustakaan jurnal ini menggunakan buku pedoman dan melalui proses literature searching terkait potensi daun jambu biji sebagai agent antidiabetik tradisional. Tahun penerbitan artikel yang digunakan adalah tahun 2005 sampai tahun 2020. Jumlah artikel yang digunakan sebanyak 17 artikel.

\section{HASIL}

Potensi senyawa bioaktif fenol dalam pemberian ekstrak etanol daun jambu biji dengan dosis $100 \mathrm{mg} / \mathrm{kg} \mathrm{BB}, 200$ $\mathrm{mg} / \mathrm{kg}$ BB dan $400 \mathrm{mg} / \mathrm{kg}$ BB dapat menurunkan kadar glukosa darah pada mencit yang diinduksi aloksan secara signifikan menurunkan kadar glukosa darah pada jam ke-2, ke-4, dan ke-6 dan diantara ketiga dosis pada dosis 200 $\mathrm{mg} / \mathrm{kg}$ memiliki penurunan lebih baik. Daun tunas muda jambu biji secara khas diperkaya dengan polifenol dengan kadar 165,61 mg / g. Penelitian lainnya dengan dua dosis $(200,250 \mathrm{~mL} / \mathrm{kg} /$ bb) ekstrak polifenol digunakan selama tiga minggu. Bahan pakan (ekstrak fenolik) dinilai untuk potensi antidiabetes menggunakan berbagai parameter diabetes, seperti glukosa darah, insulin darah, kolesterol total (TC) (Huang et al, 2011; Sukmawati, 2018).

Penelitian lainnya memberikan data bahwa uji klinis jangka panjang dilakukan untuk mengevaluasi efek konsumsi Teh Daun Jambu Biji berturut-turut dengan setiap makan selama 12 minggu pada parameter gejala diabetes pada 15 subjek laki-laki dengan pradiabetes dan diabetes tipe 2 ringan. 5 dari 7 subjek pra-diabetes menunjukkan penurunan darah $\mathrm{HbA} 1 \mathrm{c} \%$, tingkat insulin, C-peptida dan penilaian model homeostasis untuk resistensi insulin (HOMA-IR) menurun secara signifikan pada semua subjek. Selain itu, setelah konsumsi Teh Daun Jambu Biji selama 12 minggu, kadar kolesterol total (T-CHO) dan trigliserida (TG) serum menurun secara signifikan pada subjek dengan hiperkolesterolemia dan hipertriglikemia (Soman, 2013; Zhao, 2012). 


\section{PEMBAHASAN}

\section{Kandungan Daun Jambu Biji}

Peningkatan penyakit diabetes mellitus di masyarakat telah menjadi tantangan terhadap semua pihak terutama bagian kesehatan untuk dapat menemukan pencegahan yang optimal dan lebih baik. Di lain sisi makin kian hari pengobatan diabetes mellitus menemukan masalah yaitu potensi resistensi terapi farmakologi yang meningkatkan potensi mortalitas dan morbiditas. Pencarin terapi untuk menekan biaya melalui bahan alami tetap dilakukan (Anderson et al, 2019; Soelistijo et al, 2019).

Di Indonesia penggunaan herbal telah banyak dilakukan yang dikenal dengan Jamu dan sudah menjadi budaya di beberapa tempat. Pengobatan tradisional Ayurveda di India dan pengobatan tradisional Tiongkok adalah pengobatan tradisional paling tahan lama yang masih dipraktikkan. Dimana semua tradisional mencoba untuk meningkatkan kesehatan dan meningkatkan kualitas hidup, dengan terapi pada penggunaan obat-obatan asli yang berasal dari alam. Salah satu bahan yang dapat digunakan adalah jambu biji (Psidium guajava L) merupakan pohon obat kecil yang berasal dari daerah tropis dari Meksiko selatan hingga Amerika Selatan bagian utara. Pohon jambu biji telah ditanam oleh banyak negara lain yang beriklim tropis dan subtropis, sehingga dapat diproduksi seluruh dunia. Jambu biji (keluarga Myrtaceae) dan telah digunakan secara tradisional sebagai tanaman obat di seluruh dunia untuk sejumlah penyakit (Barbalho et al, 2012; Diaz-de-Cerio et al, 2017). Secara tradisional, olahan daunnya digunakan dalam pengobatan tradisional di beberapa negara, terutama sebagai obat anti diare yang dikenal di luas.
Aplikasi obatnya adalah oral atau topical sebagai obat luka secara eksternal di Meksiko, Brasil dan Filiphina. Penggunaan dengan cara rebusan, rendaman, dan olahan merupakan cara paling umum untuk mengatasi beberapa gangguan, seperti rematik, diare, diabetes melitus, dan batuk, di wilayah india, china hingga Indonesia. Bahkan di Asia Tenggara ramuannya digunakan sebagai obat kumur untuk sariawan. Varietas jambu biji yang paling umum yaitu: merah (P. guajava var. Pomifera) dan putih (P. guajava var. Pyrifera) (Diaz-de-Cerio et al, 2017).

Hasil penelitian melaporkan adanya jumlah senyawa fenolik yang lebih tinggi dengan aktivitas antioksidan pada Jambu biji putih (Psidium guajava var. Pyrifera L.) dan jambu biji merah (Psidium guajava var. Pomifera L.) jika dibandingkan dengan spesies lainnya. Penelitian $\mathrm{Wu}$ et al menemukan di dalam daun jambu biji terdapat asam galat, katekin, epikatekin, rutin, naringenin dan kaempferol. Selain itu kandungan lain yang ada dalam jambu biji adalah glikosida benzofenon galloyl baru, guavinosides A dan B, dan quercetin galloyl glycoside, guavinoside C serta lima quercetin glycosides yang diketahui dari daun jambu biji. Penelitian Kim et al mendapatkan bahwa daun jambu biji mengandung asam askorbat, asam sitrat, asam asetat, epikatekin, xantin, asam protokatekuat, asam glutamat, asparagin, asam malonat, asam trans-aconitic, asam maleat, asam cis-aconitic,asam betulinic dan lupeol (Huang et al, 2011; Kaneria, 2011; Haida et al, 2011).

\section{Mekanisme Polifenol dan Tanin Sebagai Agen Antidiabetik}

Senyawa bioaktif seperti polifenol, asam fenolik, dan tanin sangat penting 
dalam konteks ini dan telah dilaporkan berinteraksi dengan SGLT-1 dan GLUT-2. Dimana proses absorpsi glukosa usus sebagian besar difasilitasi oleh Sodium-Dependent Glucose Transporter 1 (SGLT1), sedangkan pengeluaran glukosa dari enterosit ke dalam darah dimediasi oleh Transporter Glukosa 2 (GLUT-2) .10 Namun demikian bahwa GLUT2 berada di membran apikal dimana akan mendapatkan konsentrasi glukosa luminal tinggi sehingga penyerapan glukosa didominasi dengan difusi yang difasilitasi. Sehingga, penyerapan glukosa dimediasi oleh GLUT2 merupakan target potensial tinggi untuk regulasi efektif dari kadar glukosa darah (Oh WK, 2005; Basha, 2012; Soman, 2013).

Mekanisme kerja farmakologis fenol masih terbatas. Beberapa penelitian in vitro dan in vivo telah menunjukkan efek hipoglikemik daun jambu biji dan ekstraknya melalui peningkatan sekresi insulin dimana aktivitas tersebut terdapat peran antioksidan untuk meningkatkan aktivitas reseptor sel terhadap insulin dan peningkatan pengambilan glukosa hati (Barbalho et al, 2012; Huang et al, 2011; Basha, 2012)

Ekstraksi daun jambu biji dengan air didapatkan aktivitas inhibit secara in vitro maltase, sukrase, dan alfa-amilase dengan c bergantung pada dosis. Konsentrasi penghambatan $50 \%$ (IC50) dengan dosis $0,6 \mathrm{mg} / \mathrm{mL}$ untuk alfaamilase, 2,1 mg / $\mathrm{mL}$ untuk maltase, dan 3,6 mg / mL untuk sukrase, menunjukkan aktivitas penghambatan yang lebih tinggi dari alfa-amilase dibandingkan dua enzim lainnya (Basha, 2012; Shabbir et al, 2020)

\section{Penurunan Aktivitas Enzim \\ Alfa-glukosidase}

Aktivitas Ekstrak daun jambu biji terhadap Enzim Alfa-Glukosidase. Dimana enzim alfa glukosidase berperan penting terhadap metabolism karbohidrat. Hasil penelitian menunjukkan bahwa ekstrak tersebut mampu menghambat aktivitas in vitro maltase, sukrase dan alfa-amilase. Studi secara in vivo menunjukkan bahwa ekstrak air dari daun jambu biji akan menghambat aktivitas sukrase dan maltase di mukosa usus tikus yang telah dibuat menjadi diabetes. Proses ini merupakan aktivitas yang baik dan bermanfaat sebagai antidiabetik. Penelitian lain menyatakan bahwa daun jambu biji mengandung polifenol, seperti peduncladgin, casuarinin dan isostrictinin (Barbalho et al, 2012; Shabana, 2010).

Penurunan aktivitas enzim alfaglukosidase akan menurunkan glukosa darah postprandial dimana dalam uji klinis pasien diabetes, terbukti bahwa Teh Daun Jambu Biji memiliki aktivitas pengurangan glukosa postprandial lebih ringan dibandingkan voglibose dengan mekanisme kerja acarabose. Penurunan peran enzim Alfa-glukosidase akan memiliki efek samping, seperti diare, meteorisme dan perut kembung. Efek samping didapatkan jika penghambatan enzim yang kuat sehingga glukosa tidak tercerna sampai ke usus besar dimana merangsang produksi abnormal beberapa asam oleh bakteri yang berdampak dengan penurunan $\mathrm{pH}$ usus dan pembentukan gas karbon dioksida (Kaneria, 2011; Haida et al, 2011).

Pemberian ekstrak konsumsi Teh Daun Jambu Biji berturut-turut selama 8 atau 12 minggu dalam langsung ke manusia tidak terdapat efek samping. Selain itu, penelitian in vitro menggunakan model 
hewan telah menunjukkan bahwa Teh Daun Jambu Biji dan ekstrak tidak menyebabkan toksisitas atau mutagenisitas. Selain itu Teh Daun Jambu Biji memiliki aktivitas penghambatan lemah pada isoform sitokrom $\mathrm{P} 450$, yang terkait dengan metabolisme obat antidiabetes. Hal ini menunjukkan bahwa Teh Daun Jambu Biji memiliki potensi yang lebih rendah untuk terjadi interaksi dan dapat berperan sebagai hepatoprotektor. Proses hepatoprotektor terjadi optimal pada ekstrak daun jambu biji menggunakan methanol dimana terdapat penurunan serum enzim hati (Adeyemi, 2011)

\section{Efek Hipoadinonektinemia dan Hipoglikemik}

Konsumsi Teh Daun Jambu Biji setiap kali makan meningkatkan aktivitas hipoadiponektinemia dan hipoglikemia. Sehingga menyebabkan penurunan HbA1C. Temuan ini menunjukkan bahwa Teh Daun Jambu Biji memiliki potensi terapeutik yang mirip dengan acarbose untuk meningkatkan hipoadiponektinemia dan hiperglikemia. Uji klinis menunjukkan bahwa konsumsi rutin menurunkan kadar trigilseride dan kolesterolemia. Penelitian telah menunjukkan bahwa asam galat, katekin, dan epikatekin menghambat esterase kolesterol pankreas, yang menurunkan kadar kolesterol. Katekin penting sebagai terapi pencegahan untuk diabetes tipe 2 dan obesitas. Quercetin dapat menurunkan mortalitas akibat penyakit jantung dan penurunan insiden stroke.

Quercetin menyajikan aktivitas hipokolesterolemik dan antioksidan serta efektif dalam menghambat akumulasi trigliserida dalam adiposit. Kaempferol yang terdapat pada daun jambu biji merupakan senyawa yang berhubungan dengan penurunan aktivitas HMG-CoA reduktase di jaringan hati dan memperbaiki profil lipid. Potensi antioksidan pada fenolik terhadap aktivitas penghambatan peroksidasi lipid dan aktivitas antiglikasi LDL-c, menunjukkan kontribusinya terhadap pencegahan neurodegeneratif dan kardiovaskular (Deguchi, 2010).

Kandungan lainnya berupa Asam betulinic dan lupeol dapat digunakan dalam pengobatan diabetes, penyakit kardiovaskular, obesitas dan aterosklerosis dimana tidak hanya mengurangi glikemia postprandial dan meningkatkan hiperinsulinemia pada model hewan tetapi juga berkontribusi untuk mengurangi kolesterolemia, trigliseridemia dan adiponektinemia pada hewan yang dilakukan penelitian. Penelitian lainnya ekstrak metanol dari P. guajava menunjukkan bahwa ada korelasi yang baik antara fenolik dan potensi reduktif dan korelasi antara kandungan fenolik total dan aktivitas penghambatan peroksidasi lipid.

Beberapa penelitian telah menunjukkan bahwa ekstrak air dari Psidium guajava mengandung komponen dengan aktivitas antiglikasi LDL-c. Dosis oral $250 \mathrm{mg} / \mathrm{kg}$, menunjukkan aktivitas hipoglikemik yang signifikan secara statistic (Deguchi, 2010; Zhao, 2012). Perlakuan dengan ekstrak daun jambu biji (0,01-0,625 mg / mL) menunjukkan penghambatan yang signifikan pada glikasi LDL dengan cara yang bergantung pada dosis. menunjukkan bahwa ekstrak metanol dari daun jambu biji menunjukkan efek penghambatan yang signifikan pada PTP1B (protein tirosin fosfatase 1B) dalam Tikus homozigot untuk diabetes mutasi dengan menunjukkan histologis berupa penurunan yang signifikan dalam 
jumlah lipid (Basha, 2012; Deguchi, 2010)

\section{Tingkat Keamanan Ekstrak Daun Jambu Biji}

Penelitian toksisitas esktrak daun jambu biji dalam dosis tunggal maupun dosis berulang selama 1 bulan menunjukkan bahwa pemberian oral dengan rentang dosis 200-2000 $\mathrm{mg} / \mathrm{kg} / \mathrm{hari}$ tidak menyebabkan efek abnormal pada tikus dan tidak menunjukkan bahwa adanya toksisitas akut maupun kronis. Penelitian lain tentang aktivitas mutagenik dari Teh Daun Jambu Biji maupun ekstrak didapatkan memiliki aktivitas mutagenik lebih rendah daripada teh hijau dan teh hitam dalam tes perbaikan DNA (Rec-assay); Namun, teh ini tidak menunjukkan aktivitas mutagenik dalam uji mutasi balik bakteri (uji Ames). Selain itu, Ekstrak daun jambu biji tidak menginduksi kromosom dalam tes mikronuklear menggunakan eritrosit darah perifer dengan dosis oral tunggal (2000 $\mathrm{mg} / \mathrm{kg}$ ) sehingga dikatakan bahwa tidak terdapat efek genoksitas pada ektrak maupun teh daun jambu biji (Diaz-de-Cerio et al, 2017; Shabana, 2010).

Evaluasi interaksi antara ekstrak daun jambu biji dan anti diabetes dengan obat lainnya, Penelitian Kaneko et al. mendapatkan bahwa efek penghambatan pada CYP2C8, CYP2C9 dan CYP3A4 secara in vitro dan membandingkannya dengan Jus Anggur didapatkan bahwa jus anggur menghambat hingga 10 kali lipat dibandingkan ekstrak daun jambu biji. Sebuah studi histopatologi menunjukkan tidak adanya respon terhadap induksi isoform P450 di hati tikus dengan pemberian ektrak daun jambu biji oral berulang selama 1 bulan (2000 mg / kg / hari) (Deguchi, 2010).
Konsumsi teh daun jambu biji dalam jumlah berlebihan dengan volume 3 kali lipat $(600 \mathrm{ml})$. Tidak didapatkan baik diare maupun hipoglikemia. Selain itu, konsumsi daun Jambu Biji selama 8 atau 12 minggu dengan atau tanpa obat anti-diabetes dan anti-hiperlipidemia dalam uji klinis pada manusia tidak menunjukkan efek samping atau perubahan abnormal (Oh WK, 2005; Zhao, 2012).

Temuan ini menunjukkan bahwa Teh Daun Jambu Biji dan ekstrak tidak menyebabkan toksisitas, mutagenisitas, atau interaksi abnormal dengan obat anti-diabetes dan anti-hiperlipidemia, dan memiliki potensi yang lebih rendah untuk interaksi obat berdasarkan penghambatan atau induksi isoform sitokrom P450. Dengan demikian, Teh Daun Jambu Biji dan ekstrak dapat dianggap sebagai bahan makanan yang aman. Tidak ada perubahan abnormal pada parameter fungsi hati dan ginjal, kimia darah selama masa percobaan (Balbalho et al, 2012; Huang et al, 2011).

\section{SIMPULAN}

Potensi daun jambu biji sebagai agent antidiabetik baru merupakan potensi terapi yang menjadi alternative terutama di masyarakat subtropics-tropis. Jambu biji mudah didapatkan di semua tempat. Beberapa penelitian menyatakan bahwa ada efek hipoglikemik dan hipoadiponectin dengan rentang dosis 250-2000 mg/KgBB. Kandungan antioksidan fenol dapat berdampak menurunkan efek enzim alfaglukosidase seperti layaknya antidiabetes acarbose. Efek dari hipoglikemik terutama pada glukosa postprandial menurun secara bertahap dan tidak ada efek samping. Penurunan glukosa baru terjadi setelah 4 minggu pemberian ekstrak daun jambu biji dan mencapai puncak terapi 
stabilisasi pada 8 hingga 12 minggu pemberian. Tidak ada laporan interaksi abnormal, efek samping dan mutagenisitas.

\section{DAFTAR PUSTAKA}

Anderson K, Norman D, Wittwer G. 2019. IDF DIABETES ATLAS Ninth Edition 2019.

Adeyemi OS, Akanji MA. 2011. Biochemical changes in the kidney and liver of rats following administration of ethanolic extract of Psidium guajava leaves. Hum Exp Toxicol 30: 1266-1274

Barbalho SM, Farinazzi-Machado FM V., Goulart R de A, Brunnati ACS. 2012. Psidium Guajava (Guava): A Plant of Multipurpose Medicinal Applications. Med Aromat Plants. 2012;01(04).

Basha SK, Kumari VS. 2012. In vitro antidiabetic activity of psidium guajava leaves extracts.. Asian Pacific J Trop Dis.;2(SUPPL.1):S98-S100.

Deguchi Y, Miyazaki K. 2010. Antihyperglycemic and antihyperlipidemic effects of guava leaf extract. Nutr. Metabolism 7: 9

Díaz-de-Cerio E, Verardo V, GómezCaravaca AM, FernándezGutiérrez A, Segura-Carretero A. 2017. Health Effects of Psidium Guajava L. Leaves: An Overview of the Last Decade. Vol 18.

Díaz-de-Cerio E, Rodríguez-Nogales A, Algieri F, et al. 2017. The hypoglycemic effects of guava leaf (Psidium guajava L.) extract are associated with improving endothelial dysfunction in mice with diet-induced obesity. Food Res Int.;96:64-71.
Haida KS, Baron A, Haida KS. 2011. Phenolic compounds and antioxidant activity of two varieties of guava and rue. Rev Bras Ciênc Saúde 28: 11-19

Huang CS, Yin MC, Chiu, LC. 2011 Antihyperglycemic and antioxidative potential of Psidium guajava fruit in streptozotocininduced diabetic rats. Food Chem Toxicol 49: 2189-2195.

Kamath J, Rahul N, Ashok Kumar C, Lakshmi Sm. 2008. Psidium guajava L: A review. Int J Green Pharm. 2(1):9.

Kaneria M, Chanda S. 2011. Phytochemical and Pharmacognostic Evaluation of Leaves of Psidium guajava $\mathrm{L}$. (Myrtaceae). Pharmacog 23: 3241.

Oh WK, Lee CH, Lee MS, et al. 2005. Antidiabetic effects of extracts from Psidium guajava. $J$ Ethnopharmacol. 2;96(3):411-415

Riset Kesehatan Dasar (Riskesdas). 2018. Badan Penelitian dan Pengembangan Kesehatan Kementerian RI.

Riset Kesehatan Dasar (Riskesdas). 2013. Badan Penelitian dan Pengembangan Kesehatan Kementerian RI.

Shabana S, Kawai A, Kai K, Akiyama K, Hayashi H. 2010. Inhibitory activity against urease of quercetin glycosides isolated from Allium cepa and Psidium guajava. Biosci Biotechnol Biochem 74: 878-880.

Shabbir H, Kausar T, Noreen S. 2020. In Vivo Screening and 
Antidiabetic Potential of Polyphenol Extracts from Guava Pulp, Seeds and Leaves.

Soelistijo SA, Lindarto D, Decroli E, et al. 2019. Pedoman pengelolaan dan pencegahan diabetes melitus tipe 2 dewasa di Indonesia 2019. Perkumpulan Endokrinol Indones. 1-117.

Soman S, Rajamanickam C, Rauf AA, Indira M. 2013. Beneficial effects of Psidium guajava leaf extract on diabetic myocardium. Exp Toxicol Pathol ;65(1-2):91-95.

Sukmawati, Andi Emelda, Yesi Rika Astriani. 2018. Kombinasi Ekstrak Etanol Daun Salam (Syzygium polyanthum) dan Daun Jambu Biji (Psidium guajava L.) sebagai Antidiabetes Oral pada Tikus Putih (Rattus novergicus). Pharm J Indones.;4(1):17-22.

Zhao XZ, Li XW, Jin YR, Yu XF, Qu SC, et al. 2012 .Hypolipidemic effects of kaempferide-7-O-(4'"acetylrhamnosyl) 3-O-rutinoside in hyperlipidemic rats induced by a high-fat diet. Mol Med Report 5: 837-841. 
Jurnal Penelitian Perawat Profesional, Volume 3 No 1 Hal 89 - 98, Februari 2021 Global Health Science Group 